\title{
Analysis of the Associated Factors of the Strategic Planning in SMEs of Cancun
}

\section{Análisis de los Factores Asociados de la Planeación Estratégica en Pymes de Cancún}

\author{
PERALTA-MAZARIEGO, Enrique Roberto*†, MONDRAGÓN-HARO, Antonio, MARTÍN-DE LA \\ VEGA, César Ismael and HERNÁNDEZ-PERALTA, José Carlos Ramiro
}

\section{Universidad Tecnológica de Cancún}

ID $1^{\text {st }}$ Author: Enrique Roberto, Peralta-Mazariego / ORC ID: 0000-0001-9197-879X

ID $1^{\text {st }}$ Coauthor: Antonio, Mondragón-Haro / ORC ID: 0000-0001-7698-9175

ID $2^{\text {nd }}$ Coautor: César Ismael, Martín-De la Vega / ORC ID: 0000-0003-0389-5949

ID $3^{\text {rd }}$ Coauthor: José Carlos Ramiro, Hernández-Peralta / ORC ID: 0000-0001-6521-1106

DOI: $10.35429 / J M P C .2019 .16 .5 .15 .20$

Recibido June 26, 2019; Aceptado December 28, 2019

\begin{abstract}
Strategic planning (PE) has played a very important role in the development of formal alternatives to improve organizational performance in small and medium enterprises (SMEs). The following research aims to analyze the knowledge and application of SMEs in the city of Cancun, Quintana Roo with respect to PE. A quantitative, descriptive and transversal approach was carried out. 614 managers, businessmen or SME managers participated, who voluntarily supported us referenced by students who carried out their professional practices in the period May-August 2018, January-April 2019 and May-August 2019. The information was obtained through of an instrument of own elaboration. From the results it was found that $67.4 \%$ of SMEs do not know what PE is. An important aspect to highlight is that $73.6 \%$ of SMEs do not consider training as a strategy for innovation and growth of their business. Although many of the SMEs have several years of operation, $53.6 \%$ of them do not have any element of organizational identity, Organizational Philosophy (mission, vision or values). It is concluded that SMEs are willing to consider a training plan that suits their needs as long as it does not mean unnecessary expense. On the other hand they know the importance of having an administrator with the necessary skills to adapt to changes in consumers and the global market.
\end{abstract}

Innovation, Administration, Training

\section{Resumen}

La planeación estratégica (PE) ha cumplido un papel muy importante en el desarrollo de alternativas formales para mejorar el desempeño organizacional en las pequeñas y medianas empresas (PYMES). La siguiente investigación tiene como objetivo analizar el conocimiento y aplicación que tiene las pymes de la ciudad de Cancún, Quintana Roo con respecto a la PE. Se realizó un enfoque cuantitativo, descriptivo y transversal. Participaron 614 gerentes, empresarios o encargados de pymes, los cuales nos apoyaron de manera voluntaria referenciados por estudiantes que realizaron sus prácticas profesionales en el período de MayoAgosto 2018, Enero-Abril 2019 y Mayo-Agosto 2019. La información se obtuvo por medio de un instrumento de elaboración propia. De los resultados se encontró que el $67.4 \%$ de las pymes no conocen lo que es la PE. Un aspecto importante a resaltar es que un $73.6 \%$ de las pymes no considera la capacitación como una estrategia para la innovación y crecimiento de su negocio. A pesar de que muchas de las pymes tienen varios años de operación el $53.6 \%$ de ellas no cuenta con algún elemento de identidad organizacional, Filosofía Organizacional (misión, visión o valores). Se concluye que las pymes están dispuestas a considerar un plan de capacitación que se adapte a sus necesidades siempre y cuando no signifique un gasto innecesario. Por otro lado saben la importancia de tener un administrador con las competencias necesarias para adaptarse a los cambios de los consumidores y al mercado global.

Innovación, Administración, Capacitación

Citation: PERALTA-MAZARIEGO, Enrique Roberto, MONDRAGÓN-HARO, Antonio, MARTÍN-DE LA VEGA, César Ismael and HERNÁNDEZ-PERALTA, José Carlos Ramiro. Analysis of the Associated Factors of the Strategic Planning in SMEs of Cancun. Journal of Microfinance Planning and Control. 2019, 5-16: 15-20

\footnotetext{
* Correspondence to Author (email: enrique.cieti@gmail.com)

$\dagger$ Researcher contributing first author.
} 


\section{Introduction}

Strategic planning is the action in charge of transporting an organization to the desired, this implies a direct and frequent observation of the established objectives; For this, the necessary information must be available so that the decision-making takes place according to the philosophy of the organization (Santiago and Peralta, 2015).

At present, strategic planning is a common activity in any field. In organizations, for example, it is used due to the great importance of properly managing the human resource to align it towards the fulfillment of the stated objectives (Ascencio, Campo, Ramírez and Zapata, 2016).

Therefore, its importance is best appreciated when considering the place it occupies in many well-managed organizations, convinced that its future depends on planning and technology (Govea, Cabral, Aguilar, Cruz, López and García, 2016).

The EP allows organizations to design their future, allowing them to undertake all those activities that guarantee their control of their destiny. This is how in an orderly and systematic way they find a tool that allows them to continue with the execution of all those tasks that will strengthen and focus their efforts to achieve its goals (Ascencio, Campo, Ramírez and Zapata, 2016). Under this argument the EP considers elements, which should be part of every organization:

$\begin{array}{ll}- & \text { Mission } \\ - & \text { Vision } \\ - & \text { goals } \\ - & \text { Policies } \\ - & \text { Strategies } \\ - & \text { Programs }\end{array}$

On the other hand, organizations face increasingly aggressive competition, consumers are more demanding and complex, technology changes rapidly, the liberation of international markets and the emergence of economic blocs affect what business organizations do. This requires a high willingness to train by the high command because every process must be supported by the leaders of the organizations (Cárdenas and Fecci, 2007).
On the other hand, the administration must be seen as the effort of a social or work group, coordinated and determined to obtain a common goal, with the greatest efficiency and least possible effort, considering and potentiating the resources and talents at your fingertips, looking for a objective and value for the company. (Mondragón and Hernández, 2014).

From this perspective, the future of SMEs depends on their capacity for response and innovation, so human capital represents a sustainable competitive advantage. Therefore, they must systematically and explicitly manage the activities, practices, programs and policies of the organization, where intangible assets are valued, which facilitates individual and organizational learning, solve problems of adaptation, survival and competence through organizational processes. that combine data and information processing with information and communication technologies and the innovative capacity of human capital (Delfín and Acosta, 2016).

As the way of managing the organization's knowledge and the effects it produces progresses, there have been substantial changes in the conceptual models of innovation that described it. Innovation is the future of the development of an SME. Based on López's research, Blanco y Guerra (2009) affirm the following key elements for Innovation in SMEs are: Market Orientation (OM), Creativity (CR), Research and Development (R\&D), Product Design ( DP), Operational Efficiency (EO) and Commercial Efficiency (EC).

In the city of Cancun, a large percentage of SMEs are in informality, so they have not invested in training, innovation, but they begin to show interest in improving and having growth. Under this argument, some studies have been carried out with SMEs in Cancun, obtaining the following results.

According to May, Martínez and Aguilera (2012), their study concludes the importance of developing training activities as a first step to achieve development, since there is no evidence of innovation in their processes, lack of PE for the opening of new markets or extension of existing ones. However, interest is detected by those responsible for implementing PE strategies to achieve their development. 
On the other hand, Cruz, Jimeno and Sonda (2014) in their study conclude that staff training is a determining activity for SMEs. In the same way, their results show that the implementation of technologies contribute favorably to the growth of SMEs.

\section{The purpose of the study}

The following research aims to analyze the knowledge and application of SMEs in the city of Cancun, Quintana Roo regarding PE.

\section{Methodology}

A quantitative, descriptive and transversal approach was carried out. 614 managers, businessmen or SME managers participated, who participated voluntarily referenced by students who carried out their professional practices in the period May-August 2018, January-April 2019 and May-August 2019. The information was obtained through an instrument of own elaboration, which was delivered in an envelope that they closed themselves to guarantee the confidentiality of the information. The statistical software SPSS 23 for Windows was used to process the information.

\section{Results}

The results of the study are presented below. $67.4 \%$ of SMEs surveyed do not know what strategic planning is, and only $32.6 \%$ said they know its benefits.

On the other hand, $16.6 \%$ do not consider the application of business planning important, finding an area of opportunity, in SMEs that would require support and training in this regard.

$85.8 \%$ think the reports related to the productivity of the business are important, despite the fact that the rest is of little importance or considered unnecessary. Regarding the training issue, $73.6 \%$ have not considered it for the growth of the organization, and the rest do so sporadically.

On the subject of innovation, only $33.4 \%$ actually consider innovation in the operation, while in general, the other $66.6 \%$ does not take into account the innovative aspect of their business.
Linked to the previous response, it was found that $63.2 \%$ do not devote any recourse to the issue of development and innovation; only $36.6 \%$ do something about it, while $0.2 \%$ acknowledged having no idea on the subject.

According to the managers, $74.3 \%$ have their business improvement areas very well identified, so the selection of training topics could be carried out in a simpler and more direct way. $22 \%$ say they do not have them identified, and the remaining $3.7 \%$ consider that it is not a matter of importance.

According to the literature review, training is essential for the development of an SME in this case only $52 \%$ have defined a training and training plan. In contrast to the above, $55.7 \%$ do not have manuals to carry out their activities and 66.3 do not offer training to their employees. As part of the project, questions were asked about functional areas of the organization (see annexes) that will be part of the continuation of this research project, to relate the functional areas of SMEs with training and innovation variables.

\section{Conclusions}

From the results it was found that $67.4 \%$ of SMEs do not know what PE is. An important aspect to highlight is that $73.6 \%$ of SMEs do not consider training as a strategy for innovation and growth of their business. Although many of the SMEs have several years of operation, $53.6 \%$ of them do not have any element of organizational identity (mission, vision or values). It is concluded that SMEs are willing to consider a training plan that suits their needs as long as it does not mean an unnecessary expense. On the other hand they know the importance of having an administrator with the necessary skills to adapt to changes in consumers and the global market.

It is important to highlight that SMEs expect in general and as a trend they seek to achieve growth, since 59\% expect to grow moderately, and seek support in PE, Training, security, and others in addition, curiously $31.1 \%$ would be interested in opening another branch which indicates that the interest is important on the part of the businessman to continue growing and expanding as well as to consider it in his planning. It is also important to note that $9.3 \%$ are thinking of staying the same. 
On the other hand, it is important to mention that for SME executives, $85.8 \%$ think the reports related to business productivity are important, although the rest is very large due to its lack of tools, training and management knowledge in its general context, and on the other hand $9.6 \%$ give it little importance or consider it unnecessary and prefer to continue like this.

It is necessary to specify that in this study it was detected that for SME entrepreneurs to teach courses on the growth and development of the company, $73.6 \%$ have not considered the training focused on the growth of the company, and the rest do so sporadically and very spontaneously and without much importance, so it determines a very important area of opportunity and to develop with training courses and other means.

We think it is important to mention that in terms of innovation, only $33.4 \%$ of SMEs really consider innovation in the operation, while in general, the other $66.6 \%$ does not take into account the aspect of seeking to innovate new products or services making growth and development difficult due to lack of adequate training for your business.

Similarly, it is important to mention that for SME entrepreneurs, the areas of opportunity for development and growth have been identified so that $74.3 \%$ have very well identified areas for business improvement, so the selection of training topics they could be carried out more simply and directly. On the other hand, $22 \%$ say they do not have them identified, and the remaining $3.7 \%$ consider that it is not an important issue.

\section{References}

Ascencio V., A., Campo R., J., Ramírez R., A. y Zapata C., L. (2016). Importancia de la planeación estratégica en las áreas de gestión humana de las organizaciones. Revista Fundación Universitaria Luis Amigó, 3(1), 116$122 . \quad$ Recuperado de https://www.funlam.edu.co/revistas/index.php/ RFunlam/article/view/1899/1513

Cárdenas, L., y Fecci, E. (2007). Propuesta de un modelo de gestión para PYMEs, centrado en la mejora continua. Síntesis tecnológica, 3(2), 59-67. Recuperado de http://revistas.uach.cl/pdf/sintec/v3n2/art02.pdf
Cruz, O., Jimeno, R. y Sonda, R. (2014). Relación del rendimiento de una empresa, con su tamaño, uso de la tecnología y la capacitación: análisis de las pymes de servicios en un destino turístico. Recuperado de http://risisbi.uqroo.mx/bitstream/handle/20.500. 12249/811/Cruz\%2cJimeno\%2cSonda.pdf?sequ ence $=1 \&$ is Allowed $=\mathrm{y}$

Delfín P., F. y Acosta M., M. (2016). Importancia y análisis del desarrollo empresarial. Revista científica Pensamiento y Gestión, (40). Recuperado de http://rcientificas.uninorte.edu.co/index.php/pen samiento/article/viewFile/8810/8595

Govea C., A., Cabral M., A., Aguilar V., A., Cruz H., M., López T., R., y García E., R. (2016). APLICACIÓN DE LA PLANEACIÓN ESTRATÉGICA Y FUNDAMENTO NORMATIVO EN UNA EMPRESA PROCESADORA DE CARNE. Revista Mexicana de Agronegocios, 39 , 389-398. Recuperado http://www.redalyc.org/pdf/141/14149188003.p df

Lopez, O., Blanco, M., y Guerra, S. (2017). Evolución de los modelos de la gestión de innovación. Innovaciones de negocios, 5(10). Recuperado de http://revistainnovaciones.uanl.mx/index.php/re vin/article/view/210/195

May, F., Martínez, m. y Aguilera, O. (2012). LA CREATIVIDAD Y LA INNOVACIÓN COMO ALTERNATIVAS DE SOBREVIVENCIA DE LA MICRO EMPRESA: CASO REG. 101, CANCÚN, QUINTANA ROO, MÉXICO. Global Conference on Business and Finance Proceedings, 7 (2). Recuperado de http://eprints.uanl.mx/6150/1/6.\%20ISSN1931-0285-V7-N2-

2012\%20Costa\%20Rica.pdf\#page $=1671$

Mondragón y Hernández, (2014). Básicos de la Administración. Editorial independiente, México. P9.
PERALTA-MAZARIEGO, Enrique Roberto, MONDRAGÓN-HARO, Antonio, MARTÍN-DE LA VEGA, César Ismael and HERNÁNDEZPERALTA, José Carlos Ramiro. Analysis of the Associated Factors of the Strategic Planning in SMEs of Cancun. Journal of Microfinance Planning and Control. 2019 
Santiago, A., y Peralta, M. E. (2017). Educación en ciencias Administrativas. En Barroso, F., Patrón, R. y Santos, R. (Eds). Las ciencias administrativas en el fortalecimiento de las organizaciones del tercer milenio (pp. 46-54). Recuperado

de https://www.researchgate.net/publication/31549 4940_Las_ciencias_administrativas_en_el_fort alecimiento_de_las_organizaciones_del_tercer_ milenio

\section{Annexes}

1. ¿Revisa constantemente a su competencia?

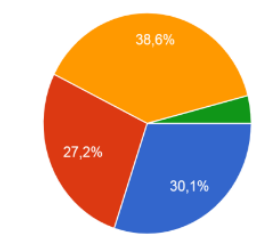

Si

No vez en cuando

- Cada vez que tengo algún problema

(1)

Figure 1Competence

2. ¿Realiza alguna estrategia para la venta de su Producto / Servicio? 614 respuestas
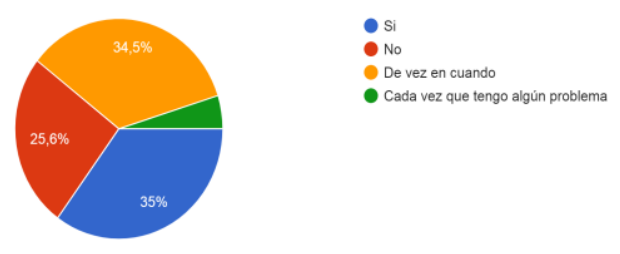

Figure 2 Sales Strategies

3. ¿Revisa si existe un producto o servicio sustituto al que usted maneja? 614 respuestas
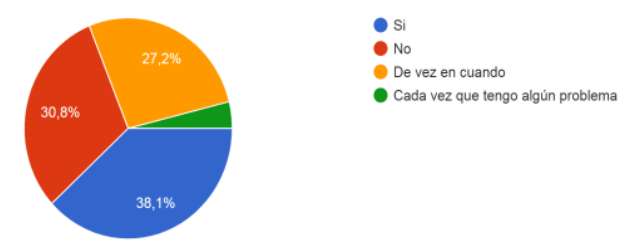

Figure 3 Competence

4. ¿Aplica encuestas del servicio o producto que ofrece?

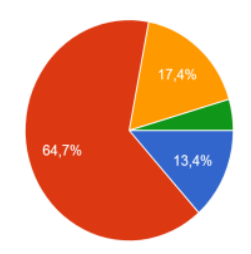

- Si

De vez en cuando
- Cada vez que tengo algún problema
5. ¿Realiza alguna comparación de precios referente a su competencia? 614 respuestas

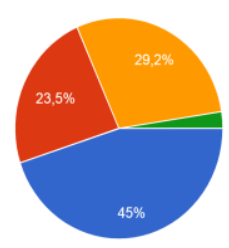

- Si

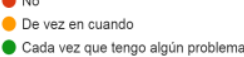

Figure 5 Price comparison

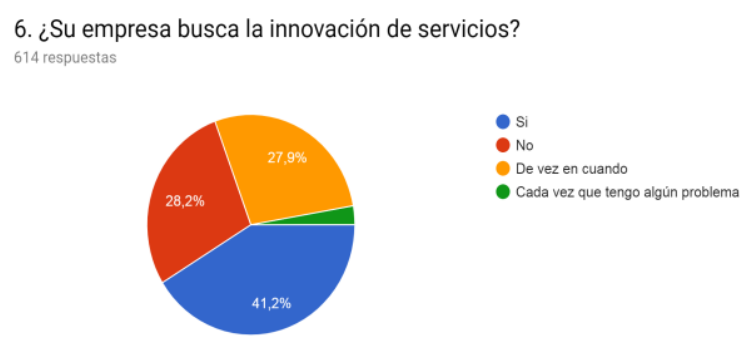

Figure 6 Service innovation

7. ¿Cuáles son las fortalezas de su empresa?
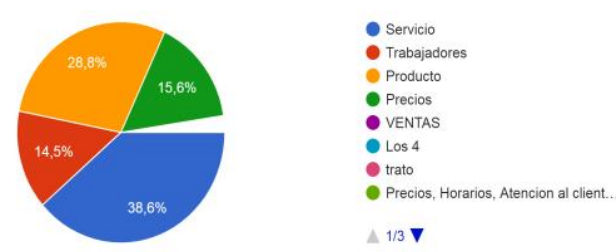

Figure 7 Company Strengths

\section{8. ¿Cuál considera que son las debilidades de su empresa?} 614 respuestas
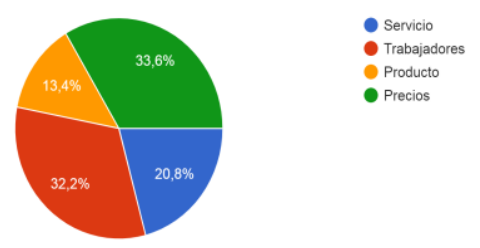

Figure 8 Company weaknesses

9. ¿Realiza alguna investigación sobre tecnologías para hacer más eficiente el trabajo?
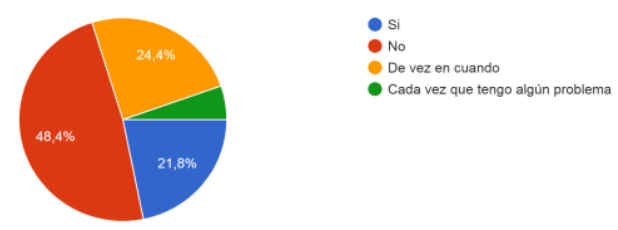

Figure 9 Research in the company

Figure 4 Service Surveys 
10. ¿Por qué medio se publicita?

614 respuestas

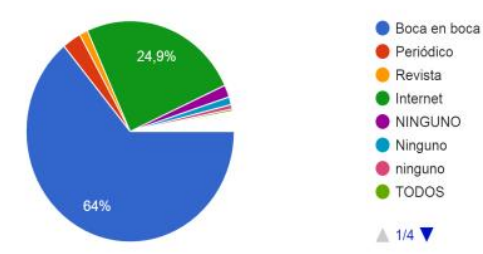

Figure 10 Advertising in the company

11. ¿Cada cuándo se promociona?

614 respuestas

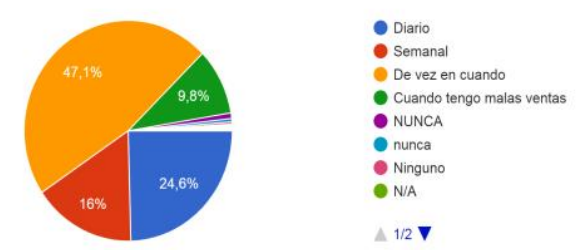

Figure 11 Promotion 